\title{
Labor and Its Efficiency in Equitized State-owned Enterprises in Vietnam
}

\author{
Thi Xuan Hong Nguyen \\ Hanoi University of Industry, Vietnam \\ Manh Dung Tran \\ National Economics University, Vietnam
}

\begin{abstract}
This study is conducted for evaluating changes in labor efficiency of state-owned enterprises after equitization. Data were collected from audited financial statements and reports of labor and average income in 138 state owned enterprises after equitization. After calculating labor efficiency according to revenue and earnings of enterprises in the sample, we apply the comparative method for labor, average income and labor efficiency before and after equitization. Then, we use the Wilcoxon Signed-Rank Test to compare the fluctuation in the ratios between two years after equitization with one year prior to equitization. The results show that after equitization, enterprises achieve an increase in average number of labor, improved average labor income and enhanced labor efficiency.
\end{abstract}

Keywords: Equitization, state-owned firm, labor efficiency, Vietnam.

DOI: $10.7176 /$ RJFA/10-5-10

Publication date:March $31^{\text {st }} 2019$

\section{Introduction}

Labor is the core force, the property and the most important factor the enterprises. They directly create products, profits for the enterprises. A firm can have modern technology, good service quality, good infrastructure but if there is a shortage of labor force working effectively, It is difficult for the firm to survive and create a competitive advantage. If the enterprise has a labor force with good professional qualifications, productivity will be higher. Besides that, the combination of labor and other inputs, the reasonable assignment and the production suitable for scale that are the factor make the success of the firm.

Low productivity has always been a big issue in State-owned enterprises due to high labor redundancy, low skill, unreasonable task assignment, and outdated machinery and equipment, which lead to frequently low productivity (Tran et al., 2006, 2007). Equitization and its policies to solve labor redundancy in equitization process provide opportunities for enterprises to reduce labor redundancy; this, together with the increase in revenue and earnings, resulted in the tendency of improved labor efficiency after equitization. In prior empirical studies about labor and labor efficiency in enterprises after equitization such as those of Tran et al. (2006, 2007), Truong et al. (2006), Tran (2007), and Doan (2014), studies with different research scope achieved different results. So after equitization, are there actual changes in the number of labor and labor efficiency in State-owned enterprises and what is the direction of change?

To clarify the fluctuation direction in the number of labor and labor efficiency in equitized state owned enterprises (SOEs), we gathered, calculated, and compared information related to the number of labor and labor efficiency before and after equitization of joint stock companies from 2002 to 2015 . We also performed Wilcoxon test on criteria about labor efficiency to clarify the direction of change.

\section{Literature Review}

Even though equitization of state-owned enterprises brings about high earnings and efficiency, the biggest concern of countries that carry out equitization is that unemployment can happen at a high rate. Therefore, changes in the number of labor and labor efficiency in state-owned enterprises after equitization gather interest of many authors. Typical studies about operational efficiency of state-owned enterprises after equitization in the world all mentioned this issue. Empirical studies showed two different viewpoints: average employement rate calculated by the average number of labor in the firm could increase (Megginson et al., 1997; Wei et al., 2003) or decrease compared to the period before equitization (Boubakri et al., 2005; Mathur \& Banchuenvijit, 2007; Oqdeh \& Nassar, 2011; Alipour, 2012). With changes in the number of labor combined with changes in revenue and earnings, most studies showed positive improvement in labor efficiency in state-owned enterprises after equitization (Megginson et al., 1997; Wei et al., 2003, Boubakri et al., 2005; Mathur \& Banchuenvijit, 2007; Oqdeh \& Nassar, 2011; Alipour, 2012). However, the study of Aussen \& Jelic (2002) showed declined labor efficiency after equitization.

Many researchers have studied about the number of labor and labor efficiency in equitized enterprises but their study samples did not include state-owned enterprises in Vietnam. As a result, with Vietnamese stateowned enterprises as the study sample, local authors based on evaluation of enterprises and international studies 
but they achieve different results. According to Amin \& Webster (1998), Sjoholm (2006), Tran et al. (2006, 2007), equitized SOEs experience a decrease in labor rate (including redundant labor) and labor efficiency. However, these studies are simply based on self-evaluated results of labor efficiency in equitized state-owned enterprises. Studies of Truong et al. (2006) and Tran (2007) applied the same comparative and verification methods like Megginson et al. (1994) and previous studies but achieved contradicting results. Studies of Truong et al. (2006) and Doan (2014) showed an increase in the average labor rate while the study of Tran (2007) indicated a decline in the average labor rate in SOEs after equitization. Regarding labor efficiency, both studies state that operational efficiency (calculated basing on the average labor rate) of state-owned enterprises equitization increases compared to the period before equitization and as a result, the average labor income also increases. The study of Vu et al. (2013) did not show the decline in labor but indicated improved labor income in equitized state-owned enterprises. However, the study of Doan (2014) showed the decline in average income after equitization.

Even though previous studies provided results of high reliability with reasonable study methods, enterprises in their study sample have the point of equitization that dated back relatively long (only up to 2004) (Tran et al., 2006; Truong et al. 2006; Tran, 2007), the research scopes were narrow or there was no comparison before and after equitization (Doan, 2013). Therefore, we combined the method of comparison before and after equitization with statistical tests and the survey sample includes enterprises with the time of equitization from 2002 to 2011 to search the answer about the difference in the number of labor and labor efficiency in state-owned enterprises after equitization.

\section{Research Methodology \\ 3.1. Data Collection}

Information about revenue, profit, labor and income of enterprises can be disclosed to interested parties but according to Jusoh et al. (2008), executives are often reluctant to provide them or participate in surveys due to the sensitive and confidential nature of information. Therefore, the chosen sample include public companies with were previously state-owned enterprises. Collected data include information about revenue, profit, labor and income of enterprises from the year prior to equitization until one to two years after equitization.

We collected information about the establishment history of public companies from the equitization of state-owned enterprises on Hanoi Stock Exchange (HNX), Ho Chi Minh Stock Exchange (HOSE), and Over the Counter Market (OTC). According to the Law on Securities, enterprises that register for listing must submit financial statements of two previous consecutive years. With the aim of collecting information 1-2 years prior to equitization, on HNX and HOSE, we focused on equitized enterprises and those that are listed on the stock exchange within 0-2 years after equitization. However, in reality, of 154 enterprises that were listed during 0-2 years after equitization, only 107 of them have information 1 year prior to equitization. As a result, there are 107 listed enterprises in the study sample.

For enterprises on OTC, we collected publicized information, if any. We also looked up website and address of enterprises, then sent open letter to them to ask for data for research purpose. Of 576 joint stock companies that were previously SOEs, we received response for data from 52 enterprises, 31 of which provided information after they become public companies - not information about the period before and after equitization. So we collected data of 31 unlisted enterprises.

After collecting information for research purposes, the study sample included 138 equitized SOEs, 107 of which are listed and 31 are unlisted enterprises.

Table 1: Overview of Research Sample

\begin{tabular}{lrrr}
\hline Stock Market & $\begin{array}{r}\text { Total } \\
\text { firms }\end{array}$ & $\begin{array}{r}\text { Equitized } \\
\text { firms }\end{array}$ & $\begin{array}{r}\text { Sample } \\
\text { firms }\end{array}$ \\
\hline Hanoi Exchange Stock Market & 430 & 294 & 58 \\
Hanoi Exchange Stock Market & 419 & 214 & 49 \\
Over the Counter Market & 1,842 & 626 & 31 \\
$\quad$ Total & $\mathbf{2 , 7 9 1}$ & $\mathbf{1 , 1 3 4}$ & $\mathbf{1 3 8}$ \\
\hline
\end{tabular}

\subsection{Data Processing}

Enterprises have different times of equitization so we categorized data not based on calendar year but based on the time of equitization. Specifically, if the year of equitization is $t=0$, the year before that is $t-1$ and the years after that are $\mathrm{t}+1$ and $\mathrm{t}+2$, respectively. Criteria about labor and labor efficiency were all considered and calculated at the points of $\mathrm{t}-1, \mathrm{t}+1$, and $\mathrm{t}+2$.

The analysis was done firstly by calculating the criteria that show labor efficiency, including:

Efficiency according to revenue $=$ net revenue/average labor

Efficiency according to earnings = earnings before tax/average labor

We used the criteria of earnings before tax because information of enterprises in the study sample was collected 
from 2001 to 2013 ; during that time, the tax levels of enterprises differed by year at the rate of $32 \%, 28 \%$, and $25 \%$. Also, according to the government's policy for equitized SOEs, these enterprises were entitled to tax incentives when they are just newly equitized. Therefore, using earnings before tax can remove the influence of tax on the earning criteria.

Next, we applied the comparative methods for criteria: mean of average labor number, mean of average income and such ratio between the time before and after equitization to evaluate the direction of change of criteria.

To achieve higher reliability for the change (if any) of ratios reflecting labor efficiency, we performed Wilcoxon Signed- Rank Test to evaluate the difference of each year after equitization compared to the year before equitization; through that the direction of change of labor efficiency in SOEs after equitization was confirmed.

\section{Results and Discussion}

\subsection{General Assessment of Labor and Average Income}

According to results of collecting information about number of labor and average income in 138 equitized, the mean data of years $\mathrm{t}-1, \mathrm{t}+1$, and $\mathrm{t}+2$ are presented in Table 2, below:

Table 2: Mean and Medium of Labor Indicator

\begin{tabular}{|c|c|c|c|c|c|c|}
\hline \multirow[b]{2}{*}{ Indicators } & \multicolumn{3}{|c|}{ Mean } & \multirow{2}{*}{$\begin{array}{c}\% \text { of increase } \\
\text { (decrease) of year } \\
t+1 \text { compared to } \\
\text { year } t-1\end{array}$} & \multirow{2}{*}{$\begin{array}{c}\% \text { of increase } \\
\text { (decrease) of year } \\
t+2 \text { compared to } \\
\text { year } t-1\end{array}$} & \multirow{2}{*}{$\begin{array}{c}\% \text { of increase } \\
\text { (decrease) of } \\
\text { year } t+2 \\
\text { compared to } \\
\text { year } t+1 \\
\end{array}$} \\
\hline & $t-1$ & $t+1$ & $\mathbf{t}+\mathbf{2}$ & & & \\
\hline Total number of labor (person) & 935 & 980 & 977 & 4.81 & 4.92 & -0.3 \\
\hline $\begin{array}{l}\text { Total average } \\
\text { (million/person) }\end{array}$ & 4.30 & 5.18 & 5.940 & 20.57 & 38.08 & 14.52 \\
\hline
\end{tabular}

Table 2 shows that the number of labor tended to increase in the year $t+1$ and year $t+2$ compared to year $t-1$ by 4.81 and $4.92 \%$, respectively but had signs of decline of $0.3 \%$ in the year $t+2$ compared to year $t+1$. This was probably because at the time of equitization, enterprises had changes in the management apparatus and technology; therefore in the first year after equitization, they recruited the new labor force suitable with the new management model and technology. They also gradually reduce unsuitable and redundant employees and rearranged their labor force. According to Tran et al. $(2006,2007)$, enterprises only resorted to dismissal when they tried all possible methods to create jobs for employees but failed to do so; in that case, employees received different incentives to ensure their life.

Average labor income in state-owned enterprises after equitization showed signs of remarkable increase. Year $\mathrm{t}+1$ increased $20.57 \%$ compared to year $\mathrm{t}-1$ but rose to $38.08 \%$ in year $\mathrm{t}+2$. Even though there was an increase in the number of labor, average income also rose and even at a higher growth rate. This increase continues to be maintained in year $\mathrm{t}+2$ compared to year $\mathrm{t}+1 \quad(14.52 \%)$. This proves that productivity of equitized SOEs was improved considerably, which led to the growth in revenue and earnings for enterprises.

\subsection{Changes in Labor Efficiency}

After equitization, labor efficiency measured by revenue and earnings of enterprises was expected to increase. Results of empirical study with survey sample show that the average revenue created by an employee in year $\mathrm{t}+1$ increased by 0.69 billion while earnings increased 0.128 billion compared to year $t-1$. This growth tendency continued in year $t+2$ with earning reaching 0.807 billion and revenue with an increase of 0.15 billion compared to year $\mathrm{t}-1$. However, in year $\mathrm{t}+2$, even though average growth and earning created by one employee still increased compared to year $\mathrm{t}+1$, the percentage of enterprises with increase in these criteria was lower than in year $\mathrm{t}+1$ and year $\mathrm{t}-1$.

After performing Wilcoxon test with two criteria reflecting labor efficiency, it could be confirmed that enterprises used their labor resources more effectively with reliability level of $99 \%$ in all paired samples. This is a good sign, showing that equitized enterprises utilized their labor resources more reasonably. This was probably due to improved average income which encouraged the labor force to work better and create more revenue and earnings for enterprises. Or it was probably because revenue and earnings of enterprises increased while the number of labor did not change much in year 1 but showed signs of decline in year 2 after equitization, which cause labor efficiency to increase. 
Table 3: Differences in Labor Efficiency before and after Equitization

\begin{tabular}{|c|c|c|c|c|c|c|c|c|c|c|c|c|}
\hline \multirow{3}{*}{ Items } & \multirow{3}{*}{$\begin{array}{c}\text { Average } \\
\text { (median) } \\
\text { before } \\
t-1\end{array}$} & \multirow{3}{*}{$\begin{array}{l}\text { Average } \\
\text { (median) }( \\
\text { in the 1st } \\
\text { year after } 2 \\
t+1\end{array}$} & \multirow{3}{*}{$\begin{array}{l}\text { Average } \\
\text { (median) } \\
\text { in the } \\
\text { 2nd year } \\
\text { after } t+2\end{array}$} & \multirow{3}{*}{$\begin{array}{l}\text { Average } \\
\text { change } \\
\text { (median) } \\
\text { in year } \\
\text { t+1 \& t-1 }\end{array}$} & \multirow{3}{*}{$\begin{array}{c}\text { Average } \\
\text { change } \\
\text { (median) } \\
\text { in year } \\
\mathrm{t}+2 \& \mathrm{t}- \\
1\end{array}$} & \multirow{3}{*}{$\begin{array}{c}\text { Average } \\
\text { change } \\
\text { (median) } \\
\text { in year } \\
\mathbf{t}+2 \& \\
\mathbf{t}+1\end{array}$} & \multicolumn{6}{|c|}{ Wilcoxon test result } \\
\hline & & & & & & & \multicolumn{2}{|c|}{$\begin{array}{l}\text { Year difference } \\
\quad t+1 \& t-1\end{array}$} & \multicolumn{2}{|c|}{$\begin{array}{l}\text { Year difference } \\
\qquad t+2 \& t-1\end{array}$} & \multicolumn{2}{|c|}{$\begin{array}{l}\text { Year difference } \\
\quad t+2 \& t+1\end{array}$} \\
\hline & & & & & & & $\begin{array}{c}Z- \\
\text { Statistic } \\
(p-v a l u e)\end{array}$ & $\begin{array}{c}\text { \% of } \\
\text { firm } \\
\text { with } \\
\text { increase }\end{array}$ & $\begin{array}{c}Z- \\
\text { Statistic p- } \\
\text { value) }\end{array}$ & $\begin{array}{c}\text { \% of firm } \\
\text { with } \\
\text { increase }\end{array}$ & $\begin{array}{c}Z- \\
\text { Statistic } \\
(p-v a l u e)\end{array}$ & $\begin{array}{c}\text { \% of firm } \\
\text { with } \\
\text { increase }\end{array}$ \\
\hline $\begin{array}{l}\text { Net } \\
\text { revenue/total } \\
\text { number of } \\
\text { average labor } \\
\text { (billion/person) }\end{array}$ & $\begin{array}{r}1.733 \\
(0.415)\end{array}$ & $\begin{array}{r}2.425 \\
(0.514)\end{array}$ & $\begin{array}{r}2.540 \\
(0.609)\end{array}$ & $\begin{array}{r}0.692 \\
(0.099)\end{array}$ & $\begin{array}{r}0.807 \\
(0.194)\end{array}$ & $\begin{array}{r}0.115 \\
(0.095)\end{array}$ & $\begin{array}{c}-4.07 \\
(.000)^{*}\end{array}$ & 71.0 & $\begin{array}{l}-5.219 \\
(.000)^{*}\end{array}$ & 77.5 & $\begin{array}{l}-6.053 \\
(.000)^{*}\end{array}$ & 71.7 \\
\hline $\begin{array}{l}\text { Earnings before } \\
\text { tax/total } \\
\text { number of } \\
\text { average labor }\end{array}$ & $\begin{array}{r}0.104 \\
(0.016)\end{array}$ & $\begin{array}{r}0.232 \\
(0.033)\end{array}$ & $\begin{array}{r}0.263 \\
\quad(0.038)\end{array}$ & $\begin{array}{r}0.128 \\
(0.017)\end{array}$ & $\begin{array}{r}0.159 \\
(0.022)\end{array}$ & $\begin{array}{r}0.031 \\
(0.005)\end{array}$ & $\begin{array}{l}-6.168 \\
(.000)^{*}\end{array}$ & 77.5 & $\begin{array}{c}-5.638 \\
(.000)^{*}\end{array}$ & 78.3 & $\begin{array}{l}-2.244 \\
(.025)^{*}\end{array}$ & 61.6 \\
\hline
\end{tabular}

(billion/

Note: (*): reliability level of $99 \%$

(**): reliability level of $95 \%$

$(* * *)$ : reliability level of $90 \%$

\section{Conclusion and Recommendations}

Through analyzing the number of labor, average labor income and labor efficiency of enterprises in the study sample, we contributes another evidence about the difference in the number of labor and labor efficiency in SOEs after equitization. Study results show that equitized enterprises did not experience decline in the number of labor; the number actually increased in 1 year after equitization. However, in two years equitization, probably because the operation of enterprises stabilized and the labor force was re-arranged so the number of labor tended to decrease but was still more than the period before equitization. This corresponds to study results of Truong et al. (2006) and Doan (2014) but contradicts to the result of Tran (2007).

Even though the number of labor tended to increase, the achieved study results are consistent with those of previous studies about the increase in average income and labor efficiency. This is probably because enterprises' improved operational efficiency resulted in increased labor welfare. Also, enterprises increase income and welfare for employees to encourage them to improve labor efficiency which helps enhance operational efficiency.

In the context where Vietnamese enterprises have been striving to improve business efficiency in general and labor efficiency in particular towards global economic integration and first and foremost the transition to adjust to the participation in the Trans-Pacific Partnership Agreement, according to we, the following recommendations need to be carried out:

First of all, enterprises should create a favorable working environment that matches with their business fields but also ensure labor safety processes. After equitization, enterprises need to pay attention to assignment of tasks and responsibilities for the labor force to put them into more suitable positions that match their capability. According to Sjoholm (2006), state owned enterprises often have a large workforce but the labor's professional skill is not high, productivity is low and there is even labor redundancy. After equitization, enterprises did not have any significant change in personnel or management; as a result, the workforce size in state owned enterprises did not show signs of decrease and even tended to increase. Therefore, equitized enterprises need to make changes towards streamlining their workforce and solving labor redundancy to improve productivity. On the other hand, they need to reduce cumbersome procedures and regulations in labor management; instead they need to be more flexible and create a better environment for employees to bring into play their potentials in suitable positions. All of these will result in improved work spirit and creativity of employees, helping them bring into play their capability, skill, expertise and increase productivity, thus creating more added value for firms.

Secondly, firms need to regularly provide training to improve knowledge and expertise for employees in each field. Nowadays, global cooperation exchanges more and more, new technical technologies are being improved constantly. Staff can be a good person at the moment but will become obsolete quickly if not refreshed for new knowledge. Therefore, the training of employees constantly is one of the basis solution to keep the labor 
efficiency. Before training, the enterprises should determine exactly training needs to choose the person who needs to training. Determination of training needs has to base on requirements of the job, not base on requirement of employees. Training program is focus on training knowledge, skill (basic and advance) for all manager, direct and indirect employees. The enterprises should create training and promotion policies to motive employees to strive better.

Thirdly, enterprises should develop new salary policy. According to Tran et al. $(2006,2007)$, salary of state owned enterprises didn't base on productivity. That did not make motivation for labor improve their productivity. So that, equitizated enterprises should change the salary policies based on productivity. In addition, they should have transparent and fair policies of reward and discipline for cases of violations and achievements.

Fourthly, we agrees with the viewpoint of Nguyen (2015) that enterprises need to perform self-evaluation of their scientific, technology and production organization level so that they can find solutions to increase their scientific level, apply modern technology and organize production in a reasonable manner. Even though the improvement of scientific level and application of advanced technology in production and business of enterprises also depend on where their budget can meet the demand, the role of organization production in a scientific and reasonable manner is mostly based on the will of the management and administration apparatus. As a result, the reasonable organization of labor force is not necessarily costly but can bring about economic benefits if the heads of unit and enterprises pay attention and take action.

Lastly, equitized enterprises need pay attention to rights and responsibilities of shareholders, especially employees as shareholders. They need to create the most favorable conditions for shareholder so that they have opportunities to study, discuss, participate, decide, and monitor issues related to their rights and responsibilities. Enterprises should improve the role of shareholders in the general meeting of shareholders, helping them understand, perform their rights, actively participate, and make decisive contributions to business and production. Through this, labor efficiency in particular and operational efficiency of the enterprises in general are improved.

This study was carried out based on the combination of the comparative method and method of statistical tests so results about the difference in labor efficiency have certain degree of reliability, this providing more evidence about operational efficiency of state owned enterprises after equitization. However, there are still shortcomings in the study sample such as (i) due to difficulties in collecting financial information for the research purpose, the study sample only includes 138 enterprises as public enterprises. The number of shareholders and scale of these enterprises are relatively large, which probably makes it easy for these enterprises to easily achieve operation efficiency in general and labor efficiency in particular; (ii) the study has not looked into reasons for the increase of the number of labor, average income and labor efficiency in state owned enterprises after equitization.

\section{References}

Amin, M.R., \& Webster. L., (1998), "Equitization of State Firms in Vietnam: Experience to date", $M P D F$ (Mekong Project Development Facility), Private Sector Discussions No. 3, Hanoi.

Alipour, M. (2012), "Has privatization of state-owned firms in Iran led to improved performance?", International Journal of Commerce and Management 23(4), 281-305, https://doi.org/10.1108/IJCoMA-03-2012-0019.

Aussenegg, W. \& Jelic. R. (2002), "Operating Performance of Privatized Companies in Transition Economies The Case of Poland, Hungary and the Czech Republic", EFMA 2003 Helsinki Meetings.

Boubakri, N., Cosset, J.C., Fisher, K. and Guedhanmi, O. (2005), "Privatization and bank performance in developing countries", Journal of Banking \& Finance, 29 (8/9), 2015-2041, http://dx.doi.org/10.2139/ssrn.391576.

Doan, T.M. (2014), "Improving financial efficiency of state-owned firms after equitization", Phd Thesis, University of Economics.

Jusoh, R., Ibrahim, D.N. \& Zainuddin, Y. (2008), "The performance consequences of multiple performance measures usage, Evidence from the Malaysian manufacturers", International Journal of Productivity and Performance Management,57(2), 119-136, https://doi.org/10.1108/17410400810847393.

Laporta, R. and Lopez, F. (1997), "The Benefits of Privatization: Evidence from Mexico", Working paper, 6215, October 1997, https://doi.org/10.1162/003355399556250.

Mathur, I. and Banchuenvijit, W. (2007), "The effects of privatization on the performance of newly privatized firms in emerging markets", Emerging Markets Review, 8, 134-146, https://doi.org/10.1016/j.ememar.2006.12.002.

Megginson, W.L, Nash R.C, Randenborgh, M.V. (1994), "The Financial and Operating Performance of Newly Privatized Firms: An International Empirical Analysis", The Journal of Finance, 49(2), 403-452. https://doi.org/10.1111/j.1540-6261.1994.tb05147.x

Oqdeh. L.N., Nassar. M.A., (2011), "Effects of Privatization on Firms Financial and Operating Performance: Evidence from Jordan", Administrative Sciences, 38(1), 288-203.

Sjoholm, F. (2006), "State owned firms and equitization in Vietnam", Working paper Stockholm school of Economics, 228, 
doi $=10.1 \cdot 1.826 .9974 \&$ rep $=$ rep1\&type $=$ pdf.

Tran, T.C., Bui, V.D., Pham, D.T., Nguyen, K.A., Nguyen, H.L., Nguyen, T.L., Trinh, D.C., (2006), "Vietnamese State-Owned Firms after Equitization: Performance, Emerging Issues, and Policy Recommendations", Vietnams Economic Management Review, 2006(1), 20-30.

Tran, T.C., Bui, V.D., Pham, D.T., Nguyen, K.A., Nguyen, H.L., Nguyen, T.L., Trinh, D.C., (2007), "Vietnamese State-Owned Firms after Equitization: Performance, Emerging Issues, and Policy Recommendations", Vietnams Economic Management Review, 2007 (2), 40-56.

Tran, G. (2007), "The impact of corporate governance on the performance of privatized firms in Vietnam", Economic Research, 2007 (2), 17-25.

Truong, L.D., Lanjouw, G. \& Lensink, R., (2006). "The impact of privatization on firm performance in a transition economy. The case of Vietnam", Economics of Transition, 14, 349-389, https://doi.org/10.1111/j.1468-0351.2006.00251.x.

Wei. Z., Oscar. V., D'Souza. J., Hassan. K., (2003) 'The financial and operating performance of China's newly privatized firm', Financial Management, 2003(32), 107 -126, doi: 10.2307/3666339 https://www.jstor.org/stable/3666339. 